\title{
Las NIIF y la relevancia valorativa de los activos intangibles: Evidencia empírica en el mercado de capitales argentino antes y después de su adopción
}

IFRS and the Value Relevance of Intangible Assets: Empirical Evidence in the Argentine Capital Market Before and After their Adoptione As IFRS e a relevância de valor dos ativos intangíveis: Evidência empírica no mercado de capitais argentino antes e depois de sua adoção

Cecilia Rita Ficco

Universidad Nacional de Río Cuarto

y Villa María, Argentina

E-mail: cficco@fce.unrc.edu.ar

Fecha de recepción: 02/04/2020 Fecha de aceptación: 24/09/2020
Palabras clave

- relevancia valorativa

- activos intangibles

- mercado de capitales argentino

- normas internacionales de información financiera

\section{Resumen}

El objetivo de este trabajo es analizar el efecto de la adopción de las Normas Internacionales de Información Financiera (NIIF) en la relevancia que el mercado de capitales argentino asigna a la información sobre activos intangibles de las empresas que cotizan en el mismo. El análisis se realiza aplicando un modelo de precios basados en Ohlson (1995), con datos recolectados directamente de fuentes originales y correspondientes al período 2009-2015. Los resultados obtenidos muestran que la adopción de las NIIF afectó la relevancia valorativa de los activos intangibles. Concretamente, la relevancia valorativa de la llave de negocio se incrementó con la adopción de las NIIF, lo que se asocia al hecho de que estas normas han regulado su tratamiento contable priorizando la relevancia de la información en mayor medida que las normas locales. En cambio, la relevancia valorativa de los otros activos intangibles identificables disminuyó con la adopción de las NIIF, lo que puede entenderse vinculado a las mayores restricciones que establece la NIC 38 en lo atinente al reconocimiento de intangibles. Estos hallazgos son acordes a los aportados por los estudios previos y contribuyen a acrecentar la evidencia existente en torno al papel que tienen los intangibles en la valoración externa de las 
Keywords

- Value relevance

- Intangible assets

- Argentine capital market

- International financial reporting standards empresas y a las implicaciones que en ello ha tenido la aplicación del marco normativo del IASB, evidencia que es particularmente limitada para mercados poco desarrollados como el argentino.

\begin{abstract}
The aim of this work is to analyze the effect of the adoption of International Financial Reporting Standards (IFRS) on the relevance that the Argentine capital market assigns to the information about intangible assets of companies that are listed on it. The analysis is carried out by applying a price model based on Ohlson (1995), with data collected directly from original sources and corresponding to the period 20092015. The results obtained show that the adoption of IFRS affected the value relevance of intangible assets. Specifically, the value relevance of goodwill increased with the adoption of IFRS, which is associated with the fact that these standards have regulated their accounting treatment prioritizing the relevance of information to a greater extent than local standards. In contrast, the value relevance of other identifiable intangible assets decreased with the adoption of IFRS, and this can be linked to the greater restrictions established by IAS 38 regarding the recognition of intangibles. These findings are in line with those provided by previous studies and contribute to increase the existing evidence about the role of intangibles in the external valuation of companies and the implications that IASB regulatory framework have had over that, evidence which is especially limited for underdeveloped markets such as the Argentine capital market.
\end{abstract}

\section{Resumo}

0 objetivo deste trabalho é analisar o efeito da adoção das Normas Internacionais de Relatório Financeiro (IFRS) na relevância que o mercado de capitais argentino atribui às informações sobre ativos intangíveis das empresas listadas nele. A análise realiza-se aplicando um modelo de preços baseado em Ohlson (1995), com dados coletados diretamente de fontes originais e correspondentes ao período 2009-2015. Os resultados obtidos mostram que a adoção das IFRS afetou a relevância da avaliação dos ativos intangíveis. Especificamente, a relevância da avaliação do patrimônio de marca aumentou com a adoção das IFRS, o que está associado ao fato de que essas normas tem regulamentado seu tratamento contábil, priorizando mais a relevância das informações do que as normas locais. Entretanto, a relevância da avaliação de outros ativos intangíveis identificáveis diminuiu com a adoção das IFRS, o que pode ser entendido vinculado às maiores restrições estabelecidas pela IAS $38 \mathrm{em}$ relação ao reconhecimento de intangíveis. Essas descobertas são acordes às fornecidas pelos estudos prévios e contribuem para acrescentar a
Palavras-chave

- Relevância de valor

- Ativos intangíveis

- Mercado de capitais argentino

- Normas Internacionais de

Relatório Financeiro 
Ficco / Las NIIF y la relevancia valorativa...

evidência existente sobre 0 papel dos intangíveis na valorização externa das empresas e as implicações que a aplicação da estrutura regulatória do IASB tem tido nesta, evidência que é particularmente limitada para mercados pouco desenvolvidos como 0 argentino.

(1) La obligatoriedad de presentación de estados financieros de acuerdo a NIIF se fijó a través de la sanción de la Resolución Técnica 26 (FACPCE, 2009). 